\title{
Effect of Irrigation Levels and Plastic Mulches on Plant Growth Parameter of Okra (Abelmoschus esculentus L.) Crop
}

\author{
A. M. Kamble", B. W. Bhuibhar, U. M. Khodke and S. V. Pimpale \\ College of Agricultural Engineering and Technology, VNMKV, \\ Parbhani-431402 (M.S.), India \\ *Corresponding author
}

\section{A B S T R A C T}

\section{Keywords \\ Okra, Drip irrigation, Plastic Mulch}

\section{Article Info}

Accepted:

10 August 2020 Available Online:

10 September 2020
A field experiment were conducted with summer okra (Abelmoschus esculentus L. Moench) during the two succeeding years i.e. summer 2017 and summer 2018, at Vasantrao Naik Marathwada Krishi Vidyapeeth, Parbhani. To evaluate the effect of different irrigation levels and plastic mulches on plant growth parameters. The effect of three drip irrigation levels viz. 0.8ETc, 1.0ETc and 1.2ETc in conjunction with transparent, black and silver-black plastic mulch were studied on plant growth and yield attributing parameters of okra. The field experiment was laid out in split plot design, in which three irrigation levels were assigned to main plots and four mulch treatment to sub plots The treatments were laid out in split plot design, in which three irrigation levels were assigned to main plots and four mulch treatment to sub plots. The study indicated that $100 \%$ irrigation requirement met through drip irrigation along with silver-black plastic mulch $\left(\mathrm{I}_{2} \mathrm{M}_{3}\right)$ gave the highest number of branches $(3.17 \mathrm{~cm})$, number of fruits $(24.71)$, fruit length $(14.93 \mathrm{~cm})$ and maximum fruit weight $(15.53 \mathrm{~g})$ and fruit yield $(476.27 \mathrm{~g})$ per plant when compared to other treatments throughout the growing period.

\section{Introduction}

Adoption of modern techniques of cultivation would result in higher output per unit of the area per unit of applied input. In arid and semi-arid, $40 \%$ to $70 \%$ of water loss is from soil surface evaporation, which can be prevented by soil covering materials (Jalota, 1993). Drip plus mulch system of cultivation is among one of the combination which is technically feasible and economically viable for almost all orchards and vegetable crops. Okra as a vegetable crop belongs to the genus
Abelmoschus, Family Malvaceae and has two main species: Abelmoschus esculentus (L) Moenchand Abelmoschu caillei (A.Chev) Stevels (Siemonsma, 1982). Originated in Africa, the plant is now cultivated in tropical, sub- tropical and warm temperate regions around the world (NRC, 2006). Okra contains carbohydrate, protein and vitamin $\mathrm{C}$ in large quantities (Adeboye and Oputa, 1996). The essential and non-essential amino acids that okra contains are comparable to that of Soybean. It was also reported by Eke et al., (2008) that fresh okra fruit is a good source of 
vitamins, minerals and plant proteins. As a result it plays a vital role in human diet; it can be consumed boiled, fried or cooked for the young immature fruits.

Okra production worldwide is estimated at six million tons per year. India is the top most country, producing 4.18 million tons of okra annually, which is around $72.9 \%$ of global okra production (FAO, 2015). In Maharashtra, the okra production in 2014-15 is 241500 tonnes from an area of 23000 ha with a productivity of 10.5 tons per ha (Department of Agriculture \& Cooperation Data for 2013-14).

The response of okra to drip irrigation in terms of yield improvement was found to be different in different agro-climatic and soil conditions in India (Tiwari et al., 1998a; Horo et al., 2003; Vankar and Shinde, 2007; Mishra et al., 2009). With this in background, present study was undertaken to study the effect of drip irrigation system and plastic mulch of okra crop under agro-climatic conditions of Marathwada region.

\section{Materials and Methods}

\section{Location and layout of field plot}

The field experiment was conducted during February to May in 2 years 2017 \& 2018 at Research Farm of AICRP on Irrigation Water Management, Vasantrao Naik Marathwada Krishi Vidyapeeth, Parbhani. Parbhani is situated in the Marathwada region of Maharashtra state at 19016' N Latitude and 760 47' E Longitudes and at altitude of 409 meters above the mean sea level. The soil of the experiment plot was clayey in texture, low in available nitrogen, phosphorus and medium in organic carbon and high in available potassium. The soil $\mathrm{pH}$ was slightly alkaline with high percentage of free calcium carbonate.
The field experiment was laid out in split plot design, in which three irrigation levels were assigned to main plots and four mulch treatment to sub plots (Fig. 1). Thus, the experiment consisted of total 12 treatment combinations which were replicated thrice. All sub plot treatments were randomized in each main plot treatment.

The treatments followed for the study were as stated below

Main plot treatments: Irrigation levels (03)

I1: Drip irrigation at $80 \%$ of crop evapotranspiration

I2: Drip irrigation at $100 \%$ of crop evapotranspiration

I3: Drip irrigation at $120 \%$ of crop evapotranspiration

Sub plot treatments: Mulches (04)

M1: Transparent plastic mulch

M2: Black plastic mulch

M3: Silver-black plastic mulch

M4: Control (without mulch)

\section{Estimation of irrigation water requirement}

Reference evapotranspiration $\left(\mathrm{ET}_{0}\right)$ was calculated using a modified Penman method (Doorenbos and Pruitt, 1977). The crop coefficient incorporates crop characteristics and averaged effects of evaporation from the soil. Holsambre (2002) was suggested the crop coefficient $(\mathrm{Kc})$ for different growth stages of okra for Marathwada region were considered.

The daily irrigation water requirement for the okra crop was estimated by using the following relationship (Tiwari et al., 1998a)

IR $=\mathbf{E T}_{\mathbf{c}}-\mathbf{R}_{\mathbf{e}}$ 
Where,

IR = Net depth of irrigation (mm day-1)

ETc = Evapotranspiration $(\mathrm{mm}$ day -1$)$

$\mathrm{Re} \quad=$ Effective rainfall $(\mathrm{mm}$ day- 1$)$

The net volume of water required by a plant was calculated by the relationship

$\mathbf{V}=\mathbf{I R} \times \mathbf{A}$

Where,

$\mathrm{V}=$ Net volume of water required by a plant (1 day plant ${ }^{-1}$ )

$\mathrm{A}=$ Area under each plant $\left(\mathrm{m}^{2}\right)$ (spacing between rows, $\mathrm{m} x$ spacing between plants, m)

The effective rainfall is the part of the rainfall that forms the part of the consumptive use. At Parbhani, the average monthly rainfall from February to May is very low as compared to rest of the months and also the potential evapotranspiration during these months is higher as compared to other months. Therefore rainfall occurring during these months was taken as effective rainfall (Michael, 2005). The irrigation water was determined after subtracting the effective rainfall from the total irrigation requirement Eq. (1).

The experimental plots of $6.6 \mathrm{~m} \times 4.5 \mathrm{~m}$ were prepared for sowing of okra seeds. The plant to plant and row to row spacing were 0.30 and $0.60 \mathrm{~m}$ respectively. The different plastic colour mulches of 30-micron thickness are transparent, black and silver-black was cut as per the size of the plots.

The data of plant growth and yield attributing parameters was recorded during okra crop growth period. The observations for number of branches, fruit length, individual fruit weight and number of fruits were recorded on five randomly selected plants in each plot.

\section{Data analysis}

The observations on growth parameters were subjected to statistical analysis of variance technique as described by Gomez and Gomez, 1984.

\section{Results and Discussion}

\section{Effect of irrigation levels and plastic} mulches No. of Branches

The data on numbers of branches per plant of summer okra as influenced by irrigation levels and different plastic mulches are presented in Table 1. The application of irrigation level 1.0ETc $\left(\mathrm{I}_{2}\right)$ was observed significantly superior over the 0.8 ETc (I1) irrigation levels with respect to number of branches per plant.

Among different plastic mulches, significantly highest number of branches per plant was observed in silver-black plastic mulches (SBPM) over the rest of mulches and control (without mulch) Interaction effect between irrigation levels and different plastic mulches was found non significant with respect to number of branches per plant of summer okra.

\section{Effect of irrigation levels and plastic mulches on fruit length}

The application of irrigation at 1.0ETc $\left(\mathrm{I}_{2}\right)$ recorded significantly higher fruit length of summer okra the rest of irrigation levels (Table 1). Among different plastic mulch treatments, silver-black plastic mulch (SBPM) recorded significantly highest fruit length of okra $(14.93 \mathrm{~cm})$ than rest of plastic mulch treatments and control (without mulch). Interaction effect between different mulches and irrigations levels was found non significant with respect to fruit length (Table $1)$. 
Effect of Irrigation levels and plastic mulches on fruit weight

The effect of irrigation levels on individual fruit weight of summer okra was significantly influenced. The application of irrigation at $1.0 \mathrm{ETc}\left(\mathrm{I}_{2}\right)$ recorded significantly highest individual fruit weight of summer okra $(13.95 \mathrm{~g})$ over the rest of irrigation levels (Table 1).

Table.1 Effect of irrigation levels and plastic mulches on okra crop parameters

\begin{tabular}{|c|c|c|c|c|c|}
\hline Treatment & $\begin{array}{c}\text { Number of } \\
\text { branches }\end{array}$ & $\begin{array}{l}\text { Fruit length } \\
\text { (cm) }\end{array}$ & $\begin{array}{c}\text { Fruit } \\
\text { weight (g) }\end{array}$ & $\begin{array}{l}\text { Number of } \\
\text { fruits }\end{array}$ & $\begin{array}{l}\text { Fruit yield per } \\
\text { plant (g) }\end{array}$ \\
\hline \multicolumn{6}{|l|}{ Irrigation level } \\
\hline $\mathrm{I}_{1}-\mathbf{0 . 8 E T c}$ & 1.99 & 12.95 & 12.18 & 21.15 & 388.41 \\
\hline $\mathrm{I}_{2}$-1.0ETc & 2.76 & 14.10 & 13.95 & 23.89 & 437.04 \\
\hline $\mathrm{I}_{3}$-1.2ETc & 2.44 & 13.35 & 13.42 & 22.78 & 416.39 \\
\hline \multicolumn{6}{|l|}{ Plastic Mulch } \\
\hline$M_{1}-$ TPM & 2.28 & 13.00 & 12.99 & 21.89 & 408.58 \\
\hline $\mathbf{M}_{2}-\mathbf{B P M}$ & 2.61 & 13.88 & 14.25 & 23.64 & 435.84 \\
\hline $\mathbf{M}_{3}-\mathrm{SPM}$ & 3.17 & 14.93 & 15.53 & 24.71 & 476.27 \\
\hline $\mathrm{M}_{4}$-Without mulch & 1.54 & 12.06 & 9.97 & 20.19 & 335.11 \\
\hline S.E. \pm & 0.29 & 0.28 & 0.30 & 0.91 & 8.54 \\
\hline C.D. at $5 \%$ & NS & NS & NS & 2.69 & 25.34 \\
\hline
\end{tabular}

C.D. $=$ Critical difference at $5 \%$ significance level

Table. 2 Number of fruits per plant as influenced by interaction between irrigation levels and plastic mulches

\begin{tabular}{|l|c|c|c|c|}
\hline Irrigation & \multicolumn{4}{|c|}{ Plastic Mulches } \\
\hline & $\mathbf{M}_{\mathbf{1}}$-TPM & $\mathbf{M}_{2}$-BPM & $\mathbf{M}_{\mathbf{3}}$-SBPM & $\mathbf{M}_{4}$-Control \\
\hline $\mathbf{I}_{1}$-0.8 ETc & 20.81 & 22.89 & 23.78 & 17.11 \\
\hline $\mathbf{I}_{\mathbf{2}}$-1.0 ETc & 23.46 & 24.38 & $\mathbf{2 5 . 4 5}$ & 22.29 \\
\hline $\mathbf{I}_{\mathbf{3}}$-1.2 ETc & 21.40 & 23.65 & 24.91 & 21.17 \\
\hline S.E. & & $\mathbf{0 . 9 1}$ & & \\
\hline C.D. at 5 \% & & $\mathbf{2 . 6 9}$ & & \\
\hline
\end{tabular}

Table.3 Fruit yield per plant (g) as influenced by interaction of irrigation levels and mulches during okra growing period

\begin{tabular}{|c|c|c|c|c|}
\hline \multirow[t]{2}{*}{ Irrigation level } & \multicolumn{4}{|c|}{ Plastic Mulches } \\
\hline & $\mathrm{M}_{1}-\mathrm{TPM}$ & $\mathbf{M}_{2}-\mathbf{B P M}$ & $\mathrm{M}_{3}-\mathrm{SBPM}$ & $\mathrm{M}_{4}$-Control \\
\hline$I_{1}-0.8$ ETc & 368.74 & 415.44 & 466.89 & 302.58 \\
\hline$I_{2}-1.0$ ETc & 438.14 & 457.08 & 489.78 & 363.16 \\
\hline$I_{3}-1.2$ ETc & 418.85 & 434.99 & 472.14 & 339.58 \\
\hline S.E. \pm & \multicolumn{4}{|c|}{8.54} \\
\hline C.D. at $5 \%$ & \multicolumn{4}{|c|}{25.34} \\
\hline
\end{tabular}


Fig.1 Experimental field layout in a Split Plot Design during 2017 and 2018

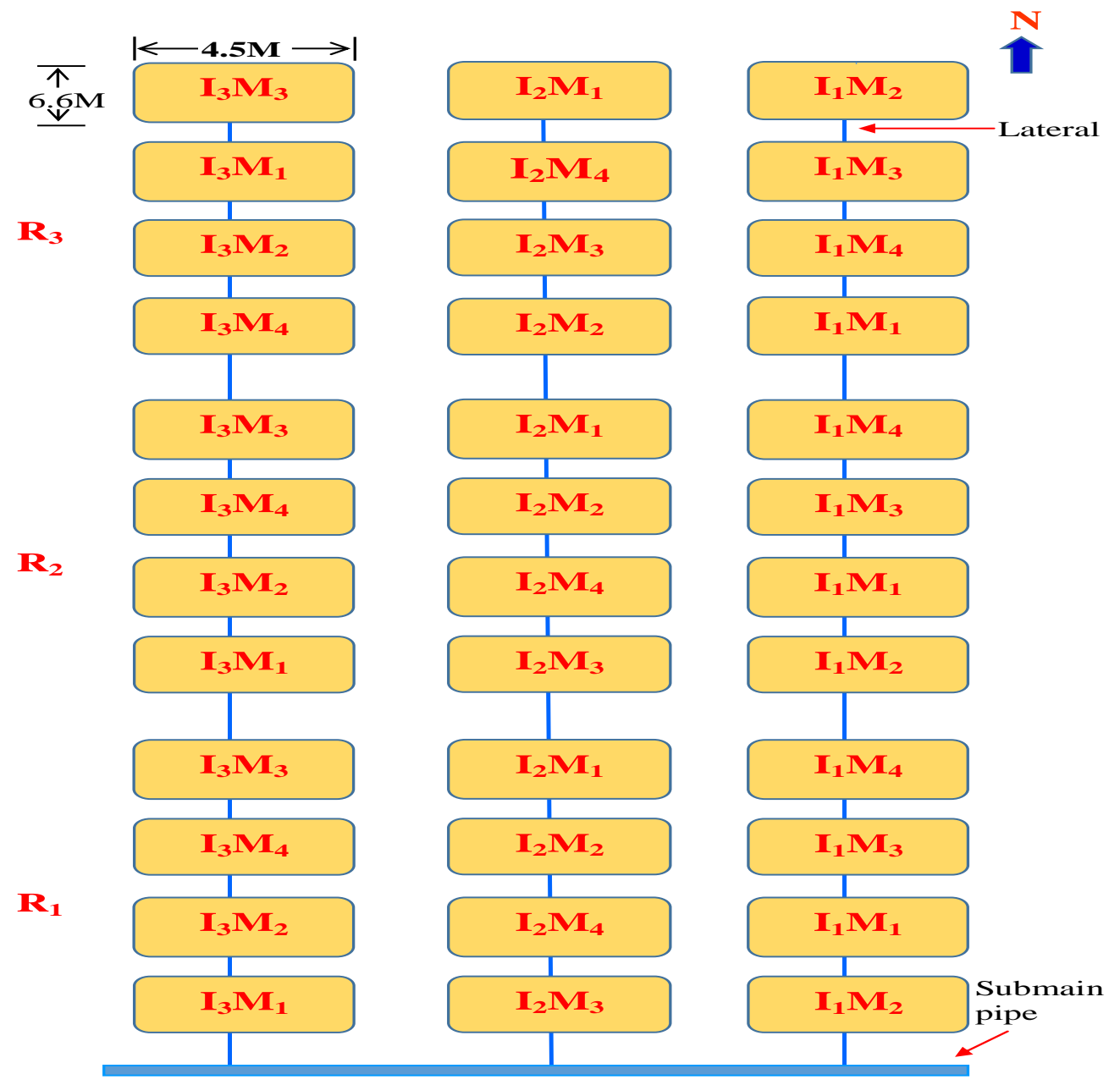

Fig.2 Effect of Irrigation levels and plastic mulch treatments on fruit yield per plant of okra

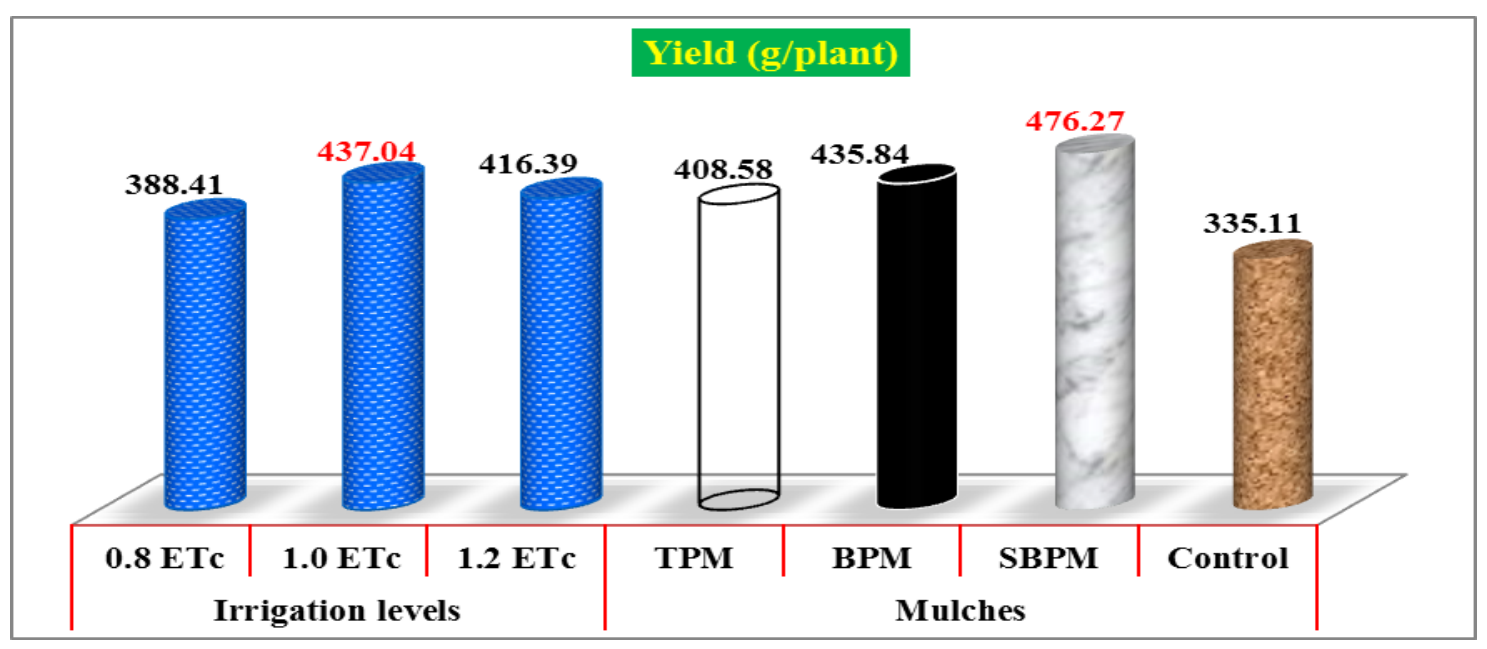


Fig.3 Interaction effect of irrigation levels and plastic mulches on fruit yield per plant (g) of okra

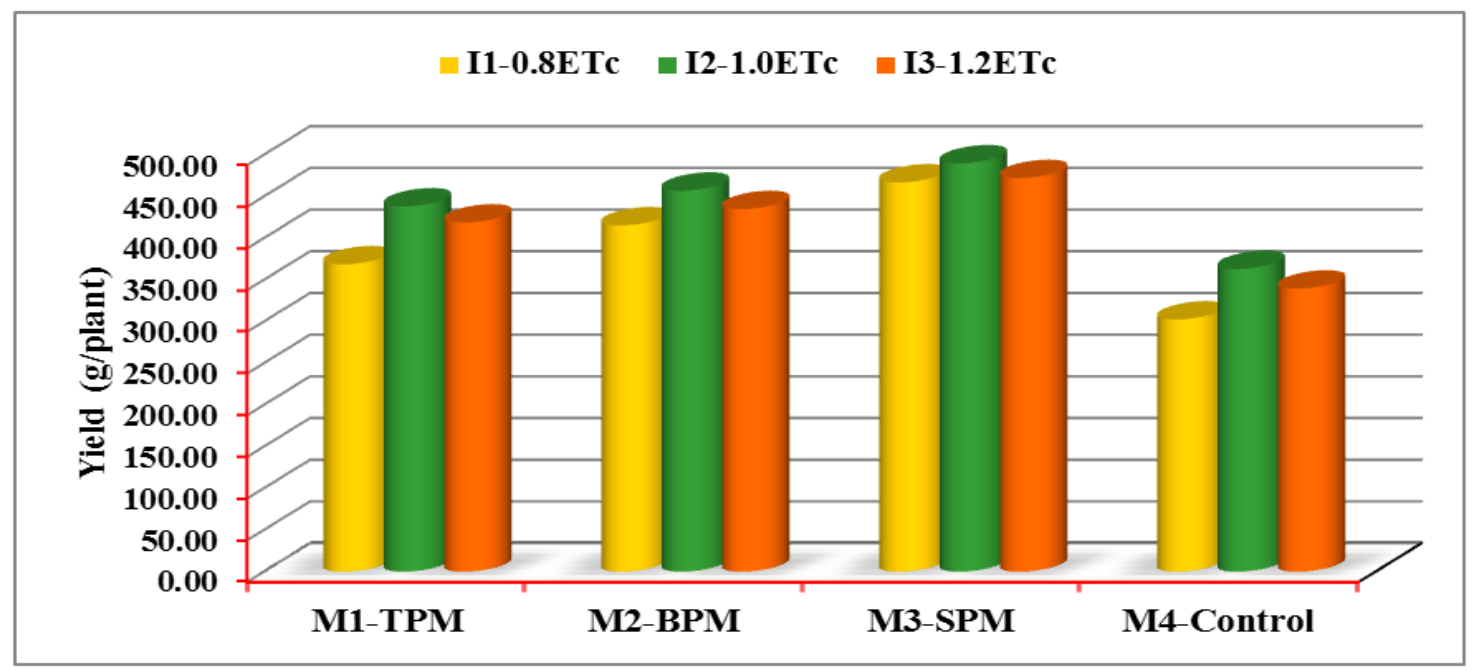

Among different plastic mulches, it is observed that pooled mean individual fruit weight of okra plant was observed significantly highest in silver-black plastic mulch treatment $(15.53 \mathrm{~g})$ followed by black plastic mulch (14.25g). Significantly, lowest individual fruit weight of okra was observed in control treatment $(9.97 \mathrm{~g})$ (Table 1$)$.

\section{Effect of Irrigation levels and plastic mulches on number of fruits per plant}

The data presented in Table 1, revealed that application of irrigation at 1.0 ETc recorded significantly highest number of fruits (23.89) per plant of okra during growth period.

Among different treatment, significantly highest number of fruits (24.71) per plant of summer okra was recorded in silver-black plastic mulch and significantly, lowest number of fruits (20.19) per plant was recorded in control (without mulch) treatment (Table 1).

Interaction effect between irrigation levels and different plastic mulches with reference to number of fruit per plant of summer okra was found to be significant (Table 2).
It is observed from Table 2 that treatment combination of irrigation at $1.0 \mathrm{ETc}$ and silver-black plastic mulch $\left(\mathrm{I}_{2} \mathrm{M}_{3}\right)$ recorded significantly highest number of fruits per plant (25.45) and was at par with irrigation at $0.8 \mathrm{ETc}$ and silver-black plastic mulch $\left(\mathrm{I}_{1} \mathrm{M}_{3}\right)$.

Plastic mulching significantly promoted vegetative growth over non mulching treatment. In mulched plots, number of branches, fruit length, individual fruit weight and number of fruits were observed. This may be as a result of the favorable environment created towards modulation potential of mulching technology. Stable moisture content and physical favorable condition of soil may have led unrestricted expanded root growth and subsequent increase in nutrient absorption. The similar results also corroborated from finding of Tiwari et al, 1998a and Mishra et al., 2009 for okra crop. $\mathrm{Ba}$ (1992) found that non-mulch plots produced cucumber plants with the least plant height, number of branches, flowers and fruits. Menezes et al., (1974), Chung (1987) and Aliudin (1986) reported that mulches conserved more soil moisture, enhanced vegetative growth and yield contributing characters of garlic. 
Effect of Irrigation levels and plastic mulches on fruit yield per plant

The data pertaining to okra fruit yield per plant $(\mathrm{g})$ under different irrigation levels and plastic mulches are presented in Table 1 and okra fruit yield per plant graphically represented in Fig. 2. Interaction effect between irrigation levels and plastic mulches with respect to okra fruit yield per plant is given in Table 3.

It is observed from Table 1 that irrigation at 1.0 ETc recorded significantly highest fruit yield (437.04 g) per plant and was at par with irrigation at 1.2 ETc. Among plastic mulches, significantly highest fruit yield $(476.27 \mathrm{~g})$ per plant of okra was observed in silver black polythene mulch as compared to rest of the plastic mulches. Significantly lowest yield was recorded in control (without mulch) treatment.

Mean fruit yield per plant of okra increased, by $42.12 \%, 30.05 \%$ and $21.92 \%$ respectively in the silver-black, black and transparent plastic mulches than the control (without mulch) and among irrigation level treatments, mean fruit yield per plant increased, by $12.52 \%$ and $7.20 \%$ respectively in the irrigation level $\mathrm{I}_{2}(1.0 \mathrm{ETc})$ and $\mathrm{I}_{3}(1.2 \mathrm{ETc})$ than irrigation level $\mathrm{I}_{1}$ (Fig. 2). From observation of Table 3, it is revealed that yield per plant $(\mathrm{g})$ of okra was significantly influenced by interaction effects of irrigation levels and mulches.

It is observed from Table 3 that treatment combination of irrigation at $1.0 \mathrm{ETc}$ and silver black polythene mulch (I2M3) recorded significantly highest yield $(489.78 \mathrm{~g})$ per plant of okra, however it was at par with irrigation at $0.8 \mathrm{ETc}$ and silver black polythene mulch (I1M3). The graphical representation of interaction between irrigation levels and plastic mulch is shown in Figure 3.
It was found that all the treatments of plastic mulching material were significantly increased the fruit yield per plant of okra. Among all mulch treatments, highest fruit yield was recorded in treatment of silverblack plastic mulch. Yield of okra was highest in plants mulched with silver-black plastic mulch, compared to other plastic mulches and without mulch. Plants under plastic mulch (silver-black) had more number of fruits and higher fruit yield per plant because of better plant growth due to favorable hydro-thermal regime of soil and weed free environment.

The above results are in consonance with those of Tiwari et al, 1998a and Mishra et al., 2009, Laxmikanth et al., 2018 for okra crop. Similar results also reported for pepper (VanDerwerken and Wilcox-Lee 1988), tomato (Bhella, 1988; Wien et al., 1993; Mashingaidze et al., 1996), maize (Fisher 1995) and watermelon (Decoteau and Rhodes 1990; Soltani 1995).

The study concluded that by using different plastic mulches and irrigation levels in commercial vegetable crop like okra that too under scarcity zone of Marathwada region is the need of hour to save water without compromising yield and quality of produce. The results of the investigation revealed that drip irrigation level 1.0 ETc along with silverblack plastic mulch produced more vigorous plant and higher yield as compared to nonmulched treatment, which facilitated in accumulation of more photosynthates and conservation of optimum temperature resulting in increased size and weight of fruits.

\section{Acknowledgement}

Authors are thankful to All India Co-ordinated Research Project on Irrigation Water Management, Vasantrao Naik Marathwada Krishi Vidyapeeth, Parbhani. 431402 (M.S.) 


\section{References}

Adeboye, O.C. and Oputa, C.O. 1996. Effect of galex on growth and fruit nutrient composition of okra (Abelmoschus esculentus). Life Journal of Agriculture, 18(1\&2):1-9.

Aliudin, T. 1986. Effect of soil tillage and application of mulch on yield of field grown garlic, Bulletin-penelitianHortikultural 8, 12-15.

Ba, Thi Tran. 1992. Vegetable production training manual, Asian vegetable Research Development Centre, Shanlva, Taindan $182 \mathrm{pp}$.

Bhella, H.S. 1988. Tomato response to trickle irrigation and black polyethylene mulch. Journal of the American Society for Horticultural

Chung, D.H., 1987. Effect of polyethylene film mulching, sulphur application and different levels of nitrogen and potassium on growth, flower stalk elongation, bulbing and leaf tip yellowing of garlic (Allium satiuum $\mathrm{cv}$. Enising). Journal of Korean Society of Horticultural Science 28, 1-8 pages.

Decoteau, D.R. and Rhodes, B.B. 1990. Characteristics and effectiveness of photodegradeable mulch for use in watermelon production. Applied Agricultural Research 5, 9-12.

FAO 2008. FAOSTAT Production. Food and Agriculture Organization of the United Nations (FAO), Rome. URL http://faostat.fao.org/site/ 339/default.aspx (last accessed 15 April 2011).

Eke, K.A., Essien, B.A. and Ogbu, J.U. 2008. Determination of optimum planting time of okra (Abelmoschus esculantus L.) cultivars in the derived Savannah. Proceedings of the 42nd Annual Conference of Agricultural Society of Nigeria (ASN).October 19th to 23rd at Ebonyi State University, Pp.: 242 -
245.

Holsambre, D.G. 2002. Drip Irrigation Management, Aurangabad: Saraswati Printing Press ltd.

Horo, P., Chowdhary, B.M., Prasad, B.N. and Kandeyang, S. 2003. Effect of micro irrigation on growth and yield of okra in Jharkhand, India. The Orissa Journal of Horticulture, 31(2): 80-83.

Jalota, S.K. 1993. Evaporation through soil mulch in relation to characteristics and evaporativity. Australian Journal of Soil Research, 31(2):131-136.

Laxmikanth, Mallikarjun, Rubeena Tarranum and Kavitha. 2018. Effect of colour plastic mulching and different levels of drip irrigation on plant growth parameters of okra (Abelmoschus esculentus) Crop. Journal of Pharmacognosy and Phytochemistry, SP1: 3184-3188.

Mashingaidze, A.B., Chivinge, O.A. and Zishiri, C. 1996. The effects of clear and black plastic mulch on soil temperature, weed seed viability and seedling emergence, growth and yield of tomatoes. Journal of Applied Science for South Africa, Vol. 2 (1): 6-14.

Menezes, S.M., Navais, D.E., Sontos, H.L., Dos, M.A. 1974. The effect of nitrogen fertilization, plant spacing and mulching on the yield of garlic cultivar Amarante, Revista Ceres, 21: 203-211.

Michael, A.M., 2005. Irrigation Theory and Practice. Reprint 1st ed. Vikas Publishing House, New Delhi, India, pp.: 537-547.

Mishra, J.N., Paul, J.C. and Pradhan, P.C. 2009. Response of okra to drip irrigation and mulching in coastal Orissa. Indian J. Soil Cons., Vol. 37(2): 129-132.

National Research Council (NRC) 2006: Lost Crops of Africa: Volume 11: Vegetable, National Academic Press.

Siemonsma, J.S. 1982. The cultivation of okra 
(Abelmoschus SPP.), tropical fruitvegetable with special reference to the Ivory Coast. D.H.O., Thesis, Wageningen. Agricultural, Wageningen, the Netherland. 297pp.

Soltani, N., Anderson, J.L. and Hamson, A.R. 1995. Growth analysis of watermelon plants grown with mulches and row covers. Journal of the American Society for Horticultural Science, 120(6): 1001-1009.

Tiwari, K.N., Mal, P.K., Singh, R.M. and Chattopadhya, A. 1998a. Response of okra to drip irrigation under mulch and non-mulch conditions. Agricultural Water Management, ELSEVIER, 38(2): 91-102.
Van Derwerken, J.E. and Wilcox-Lee, D. 1988. Influence of plastic mulch and type and frequency of irrigation on growth and yield of bell pepper. HortScience, Vol. 23(6): 985-988.

Vankar, R.R. and Shinde, P. P. 2007. Effect of micro-irrigation systems and polythene mulches on yield and yield attributes of okra. The Orissa Journal of Horticulture, 35(1): 22-26.

Wien, H.C., Minotti, P.L. and Grubinger, V.P. 1993. Polyethylene mulch stimulates early root growth and nutrient uptake of transplanted tomatoes. Journal of the American Society for Horticultural Science, Vol.118 (2): 207-211.

\section{How to cite this article:}

Kamble, A. M., B. W. Bhuibhar, U. M. Khodke and Pimpale, S. V. 2020. Effect of Irrigation Levels and Plastic Mulches on Plant Growth Parameter of Okra (Abelmoschus esculentus L.) Crop. Int.J.Curr.Microbiol.App.Sci. 9(09): 857-865. doi: https://doi.org/10.20546/ijcmas.2020.909.108 